\title{
Maintenance, repair, and operations inventory reduction and operational development
}

\section{Matias Siponen, Harri Haapasalo and Janne Harkonen*}

Industrial Engineering and Management,

University of Oulu, Finland, P.O. Box 4610,

FI-90014 University of Oulu, Finland

e-mail: matiassiponen@gmail.com

e-mail: harri.haapasalo@oulu.fi

e-mail: janne.harkonen@oulu.fi

*Corresponding author

\begin{abstract}
Emphasis on maintenance, repair, and operations inventory (MRO inventory) can lead to improvements in inventory control and productivity while reducing operational costs. This study focuses on different approaches to optimising and reducing spare part inventories by addressing the development of MRO inventory operations and by analysing the development efforts of an urban energy company. The results indicate that typical challenges faced in inventory control are due to inadequate control and management policies and procedures. Three main viewpoints are emphasised to developing spare part inventory operations, with a broad focus, including: material management, supplier management, and information system management. The need to adopt business process management methods to enable successful continuous development of the spare part inventory processes is also highlighted. A potential framework for the MRO inventory management development process is developed as a result of the findings, and the role of correct roles and responsibilities within the organisation is highlighted.
\end{abstract}

Keywords: Inventory; spare part; maintenance, repair, and operation (MRO) inventory reduction; industrial and systems engineering; process development; process management.

Reference to this paper should be made as follows: Siponen, M. Haapasalo, H. and Harkonen, J. (2019) 'Title', Int. J. Industrial and Systems Engineering, Vol. 32, No. 1, pp.1-31.

Biographical notes: Matias Siponen holds both Bachelor's degree and a Master's degree in Industrial Engineering and Management, from the University of Oulu, Finland. He has both research interests in and industrial experience in the field of maintenance, repair, and operations 
inventory reduction and operational development. Matias is currently working on related topics in the industry.

Dr Harri Haapasalo is a Professor of Product Management at Industrial Engineering and Management, University of Oulu in Finland. He has two main areas of research; one in product management, product development and second one in area of complex systems management, lean construction and business models. He has been very active in obtaining research projects, and active in journal publications. His list of publications contains more than 200 international items. He has supervised more than 20 doctoral theses and been external examiner for more than 20 doctoral dissertations.

Dr Janne Harkonen received his Bachelor's degree (1st Class Honours) in Engineering Business Management from University of Greenwich in the UK and both his M.Sc. in Process Engineering and Dr (Tech) in Industrial Engineering and Management, from the University of Oulu, Finland. He has also studied in the University of North Carolina at Wilmington, USA. He has experience working in the IT, service and environmental technology industries. Currently, he is a senior research fellow at the University of Oulu in Finland. Dr Harkonen has authored and co-authored over fifty journal articles, and a number of other publications. 


\section{INTRODUCTION}

Spare part inventory management incurs significant costs in capital intensive industries (Sarker and Hague, 2000). Maintenance, repair, and operations (MRO) inventories are needed to support the repair and maintenance of technical installations and production systems (Bailey and Helms, 2007). MRO inventories differ from other production related inventories in several ways. In production work, work-in-process (WIP) inventories exists in order to smooth out changes in a production flow, and finished product inventories smooth out irregularities in supply and demand. WIP and finished product inventory levels can be affected by decisions concerning production capacity, schedule, or supply chain while spare part inventories are largely linked to how equipment is maintained and used (Kennedy et al., 2002). Nevertheless, the reduction of MRO inventories is a relatively neglected area of investigation (Younis et al., 2013).

Eaves and Kingsman (2004) have recognised how spare parts often have intermittent or slow-moving demand patterns and thus present unique problems for inventory management and forecasting. Technical installations, being nowadays increasingly complex and involving increasing numbers of components, have difficulties in spare part management. Industrial systems have become more complex, which makes service and spare part availability more critical. Maintenance has significance for the optimal production rate - merely considering machines while uptime and downtime are stochastic can be problematic (Sajadi and Rad, 2016). The lack of spare parts may lead to significant production losses without compensation. Due to the possibility of high losses, in the case of obsolescence of an item, the inventory service level is usually kept relatively high (Bailey and Helms, 2007). Hence, traditional inventory management methods cannot be directly applied in a maintenance environment (Bailey and Helms 2007; Huiskonen, 2001). Kennedy et al. (2002) have also noticed that spare part inventories have a unique relationship to management issues, age-based replacement, multi-echelon decisions, and obsolescence. Sratman (2005) points out how spare part inventories require hard work and discipline to keep the process in control.

According to Mehotra et al. (2001), investments in spare part inventory typically account for 5 to $10 \%$ of a company's investment base. Hence, a reduction in spare part inventory can translate into substantial savings when the carrying cost is high. Nevertheless, the challenge in spare part management is finding the optimal service level of critical spares as inventory costs and production losses are conflicting factors (Cardamone, 1996). Sleptchenko et al. (2005) show that repair priorities have an impact on required stock investment. Typically the situation is rather complex since there are multiple other criteria that should be considered: price, stocking limitations, safety and environmental issues, maintenance strategies, and logistics characteristics (Braglia et al., 2004). In addition, the quality of spare parts has prime importance for supplier choice (Pfohl and Ester, 1999). Spare part demand forecasting is very challenging if stocks are not regularly replenished since breakdowns are difficult to estimate accurately (Vaughan, 2005). Some spares also have significantly long lead-times and thus must be stocked in inventory (Bailey and Helms, 2007; Huiskonen, 2001). Production loss assessment in the case of a stock-out can turn out be a challenging task, particularly if relations between phenomena are not well-known (Kennedy et al., 2002).

Earlier studies have suggested several methods for spare part management, but they have proved more or less impractical for various reasons. Methods used for managing WIP or finished goods inventories, such as Wilson's model, can be misleading due to inaccurate and unreliable data, but also due to high volatility in consumption (Bailey and Helms, 2007; Huiskonen, 2001). Existing studies on spare part management practices indicate typical industry problems. Aberdeen (2006) points out that companies 
performing worse than the average have pitfalls in their MRO inventory management. Earlier studies have particularly found pitfalls in management systems since the inventory practices and methods employed are not commonly acknowledged and adopted (e.g. Bailey and Helms, 2007; Cavalieri et al., 2008). However, most earlier studies have only had one eye on spare part management (e.g. Cavalieri et al., 2008; Huiskonen, 2001; Molenaers et al., 2012). There is a clear lack of research on MRO inventory operations as a whole business process and on the related performance improvement. Simply forecasting consumption may not the best way of overall efficiency development. It might be more sensible to develop the responsiveness of the replenishment process and related systems.

This study focuses on opportunities to reduce MRO inventories by considering improvements in the efficiency of operations and related systems. The aim is to find key avenues for development. Furthermore, the best practices in each approach are identified. The purpose of this paper is to present targets for MRO inventory development and methods to achieve targets concerning MRO inventory management. 


\section{LITERATURE REVIEW}

Literature relating to the management of MRO inventory is extensive (Kennedy et al., 2002; Molenaers et al., 2012). There are different approaches to studying challenges in spare part management, and quite a lot of the literature diverges or concentrates on rather small details. Overall, spare parts aside, manpower is vital for carrying out maintenance work (Mahmood et al., 2011). Regardless of the versatility of the literature, three main viewpoints arise: material management (e.g. Cavalieri et al., 2008; Molenaers et al., 2012), supplier management and spare part logistics (e.g. Huiskonen et al., 2001) and information system management (e.g. Pingping and Feng, 2009; Otto et al., 2007). In addition, Bailey and Helms (2007) have highlighted the importance of business process management in spare part management as an umbrella element. Nevertheless, focusing on a single spare part management process is not enough to reach target results considering MRO stocking as a business process. Instead, the successful development of MRO inventory requires both cross-functional involvement and commitment by senior management (Bailey and Helms, 2007; Yingling, 1997). Hence, it is important to identify spare part stocking as a business process and appreciate its role in a capital intensive business. It should be managed as any other business process.

H1: The approaches to developing MRO inventory operations are versatile, yet a more comprehensive perspective may be needed for effective operations.

Once a company has identified the need to improve the efficiency of MRO inventory operations, execution can be organised by senior management to ensure success (Harrington, 1995; Lee and Dale, 1998). Managers determine the departments that should be involved, for example accounting, maintenance, production, procurement, quality control, logistics, and information management (Bailey and Helms, 2007; Kang and Gerswing, 2004; Yingling, 1997). In particular, production planning, scheduling, maintenance, and quality are often discussed independently when they should instead be considered in an integrated manner (Hadidi et al., 2012). Yingling (1997) also proposes documenting inventory related processes by mapping and flowcharting to ensure an understanding of the processes, the importance of different departments and persons in certain process, and relevant interactions. Based on this information, managers can form a project or development team including leaders of involved departments. The team leader should be the person who owns the MRO inventory concept (DeToro and McCabe, 1997). For team success, the team must understand its missions and boundaries. Thus, the management team plays a key role in developing missions that fit with the targets of the organisation (Lee and Dale, 1998). In the case of MRO inventory, the target may be to achieve the target inventory level or service level (Bailey and Helms, 2007). According to business process management principles, Lee and Dale (1998) recommend setting measures for quality and performance concerning every process. Once a mutual commitment to measures and targets has been achieved, project team members then ensure that their own departments reach the targets. However, it is especially important that the targets aim to optimise MRO inventory as a whole business process because focusing on one single process may lead to a sub-optimised business process. (Zairi, 1997)

Both supplier management and information system management are tightly related to material management operations and vice versa. An interface between these concepts is, however, created for simplicity. Decisions on one of these three spare part management process viewpoints have an effect on the other two. Thus, decision making in this kind of multi-criterion operating environment can prove a very challenging task (Molenaers et 
al., 2012). Material management can be divided into four sub-processes in spare part management: part coding, part classification, part demand forecasting, and establishing re-order points and quantities (Cavalieri et al., 2008; Huiskonen, 2001; Moleaners et al., 2012). Similarly, supplier management can be divided into three sub-processes: identifying characteristics of spare part logistics, developing strategies for spare part logistics, and supplier coordination and control (Bailey and Helms, 2007; Huiskonen, 2001). Finally, information system management can also be divided into three subprocesses: automation of ordering processes, data quality control, and supplier integration into information systems (Gunasekaran and Ngai, 2004; Kang and Greshwin, 2004; Wende, 2007; Weng-Young et al., 2011).

H2: A suitable combination of supplier management, material management, and information system management is necessary for developing spare part inventory operations with adequate business process considerations.

H3: Supplier management, material management, and information system management may involve challenges that influence spare part inventory operations and potentially the more holistic perspective.

H4: Companies' development targets and the efforts to achieve those targets can improve spare part inventory operations.

\section{Material management}

Material management is a key element in spare part inventory management as almost all stocking operations are based on it (Cavalieri et al., 2008). Hence, it is critical that every person impacting MRO inventories understands and adopts mutual material management practices. This can be enabled by mapping and documenting material management subprocesses (Bailey and Helms, 2007; Yingling, 1997). For example, part coding must be carefully considered to ensure that all the required information is available in the information systems (Cavalieri et al., 2008). Recorded data should fulfil every user's information needs, both internal and external users (Otto et al., 2007). Cavalieri et al. (2008) suggest registering, at minimum, information about part suppliers, lead-times, physical location in the inventory, the equipment tree it resides in, and price.

Spare part classification supports all other spare part management practices (e.g. Cavilieri et al., 2008; Huiskonen 2001; Moleaners et al., 2012). Spare part classification in a multi-criterion operating environment can be challenging as most frameworks proposed by the literature are quite impractical and tough to exploit (Moleanaers et al., 2012). Common methods for classifying spare parts are necessary to simplify assessment processes concerning other spare part management practices (Cavalieri et al., 2008). For example from a logistics viewpoint, the critical decision is whether a spare part should be stocked in one's own inventory or delivered once the demand occurs (Huiskonen, 2001). In addition, a common way to classify spares would enable the exploitation of portfolio management tools. A certain cohesion in practices would support the management of spare part stocking. Methods such as VED-AHP analysis have been proposed for classifying spare parts (Cavalieri et al., 2008; Moleaners et al., 2012). Usability and reliability are desired, yet the classification method should consider at least equipment breakdown effects, maintenance strategy, spare part lead-times, availability, and value and consumption (Cavalieri et al., 2008; Huiskonen, 2001; Moleanaers et al., 2012). Referring to business process management principles (e.g. Lee and Dale, 1998), classification methods should be continuously assessed and developed according to 
requirements. Non-value adding activities within maintenance operations need to be reduced through various tools and strategies (Sawhney et al., 2009).

Spare part demand forecasting is discussed in relation to both order planning and inventory planning. Spare part demand forecasting is one of the most important actions that relate to part classification (Cavalieri et al., 2008; Huiskonen, 2001; Tucci, 2006). Demand forecasting can be executed based on either reliability or historic information (Cavalieri et al., 2008). If enough historic data about consumption of spare parts is available, time-series-based forecasting techniques, such as modified Croston methods, can be exploited (Wang and Syntetos, 2011). By contrast, if no historic data is available, reliability-based forecasting techniques might prove necessary. According to Cavalieri et al. (2008), potential information sources for reliability-based forecasting include spare part suppliers or databanks that offer information about failure rates. Companies should also consider the number of identical spare parts installed in each piece of equipment as well as operating conditions (Cavalieri et al., 2008).

Establishing re-order points and re-order quantities aids the optimisation of inventory levels and enhances service levels, particularly in the case of high volume spare parts (Bailey and Helms, 2007). The determination of re-order points is based on consumption during lead-time and safety stock, which aim to ensure availability even though there are irregularities in demand or lead-times (Costa and Silver, 1995; Wang and Zhang, 2008). Nevertheless, both Lau et al. (2006) and Bailey and Helms (2007) criticise the applicability of popular inventory models in spare part management due to their multiple criteria and uncertain operational environment. According to Shamsaddini et al. (2015), most inventory and spare part management methodologies are either too intricate or oversimplified, which reduces their efficiency from the perspective of a maintenance manager. Thus, adopting those techniques should be carefully considered, including the characteristics of spare part class. For example, should an economic order quantity model be considered for spare parts? The uncertainties relating to demand rate and order cost must be acknowledged (Yu, 1997). Overall, modern inventory control for capital goods, including different models, is well covered by Van Houtum and Kranenburg (2015). Most enterprise resource planning (ERP) systems support re-order planning process and offer opportunities for automation (Huiskonen, 2001; Weng-Yong et al., 2011) By automating the ordering process, a company can achieve significant cost cutting related to inventory holding costs and labour costs (Gunasekaran and Ngai, 2004; Pintelon et al., 1999; WengYong, 2011).

\section{Supplier management}

In spare part management, supplier management stands for the planning and designing of spare part logistics systems. Characteristics of spare parts, such as criticality, specificity, value of parts, and demand have an effect on logistics system elements (Huiskonen, 2001; Moleanears 2012). As Huiskonen (2001) lays out, these elements are network structure, positioning of materials, responsibility of control, and control principles. Thus, choosing the supply strategy depends on the characteristics of spare parts. However, close cooperation with suppliers and information sharing enables shorter lead-times and enhances confidence between the parties (Huiskonen, 2001). According to Gunasekaran and Ngai (2004), the role of information systems in supplier management is quite significant since it enhances information flows, confidence, and the quality of operations.

Spare part logistics relevant to supplier management touches on topics such as maintenance requirements, production and inventory control, and supply chain management, and some strategic management aspects necessitate effective strategies for spare part logistics (Huiskonen, 2001). The important considerations include: standard vs. user-specific parts, availability, predictability of demand, value, and criticality. 
Standard parts availability is typically good as there are many users, but user-specific parts involve such tailored parts that suppliers are reluctant to hold stock (Jajimoggala et al., 2012). Demand predictability can be classified into parts with random failures and parts with a predictable wearing pattern (Zeng and Wang, 2010). Holding costs for expensive spare parts can be extremely high, impacting value considerations (Klein Haneveld and Teunter, 1997). The criteria for critical spare parts is somewhat industry specific, involving the industry characteristics of logistics and maintenance (Armenzoni et al., 2015; Braglia et al., 2004).

\section{Information system management}

ERP systems support material management processes by enabling automated ordering processes (Weng-Yong et al., 2011). Automating order processes can enable significant savings through smaller stock value and personnel costs (Gunasekaran and Ngai, 2004; Pintelon et al., 1999; Weng-Yong, 2011).

Data quality control is vital from an information system management viewpoint as pure documentation is not enough - controlling the quality of data is also required (Silvola et al., 2016; Wende, 2007). Companies should have an established data quality organisation that is responsible for the quality of data. Data quality metrics must be specified in addition to performance indicators and standards. (Otto et al., 2007). According to Kang and Gershwin (2004), the quality of data contributes to both stock value and service level.

The level of information system integration is one aspect of supplier integration that can reduce costs and enhance relationships through real-time information management and communication (Armistead and Mapes, 1993; Ryan, 2001).

\section{Business process management}

Business process management (BPM) is relevant for considering businesses and business management as a whole (Hammer, 2002). BPM provides an approach to process improvement, enabling a transition from an uncooperative to a synergy strategy (Baldassarre et al., 2016). BPM is a methodology by which an organisation's personnel can aim towards improving business processes and reaching a set business targets (Lee and Dale, 1998). BPM relates to key processes that are identified, described, and documented. Process management must be based on continuous problem solving and reaching towards higher gains (Hammer, 2002; Lee and Dale, 1998; Zairi, 1997). Even though BPM covers all key processes organisation-wide, developing individual processes is necessary. This is supported by Bailey and Helms (2007) who emphasise the importance of organisational commitment to reducing stock value. The common model of operations provided by BPM supports avoiding sub-optimisation through organisationwide development, cooperation, and employee empowerment (Lee and Dale 1998; Trkman, 2010).

\section{Synthesis}

The development of MRO inventory operations consists of BPM, material management, supplier management, and information system management (Figure 1). The framework shown synthesises the literature review into a visual aid for developing MRO inventory operations to aid perception of the different approaches from a more comprehensive perspective. The role of BPM is to act as an umbrella concept for the others. According to Bailey and Helms (2007), an MRO inventory development project should be a continuous process and follow the principles of BPM. Yingling (1997) agrees with this. 
Different approaches for spare part management and related processes should also be considered in order to find best practices along with the MRO inventory development team.

\section{[Please insert Figure 1 here]}

Figure 1. Theoretical framework for developing MRO inventory management. 


\section{RESEARCH PROCESS}

\subsection{Research method}

Figure 2 illustrates the research process applied in this study. First, the aim of the literature review was to obtain an adequate outline of the MRO inventory processes and operations. In addition, the literature review focuses on managerial perspectives of MRO inventory. The interview structure was created from the theoretical framework. Second, company representatives were interviewed to clarify current practices and challenges relating to MRO inventory. The data obtained was analysed and finally conclusions were drawn.

\section{[Please insert Figure 2 here]}

Figure 2. Research process.

The empirical material was collected by interviewing representatives from a case company. The interviewees were selected based on departments presented in the theoretical framework. Furthermore, the representatives of each department were selected based on their broad knowledge and relationship to the subject. The interviews covered company functions broadly, including maintenance, accounting/finance, production, MRO inventory itself, procurement, quality control, and data management. Appendix A contains the interview questions. Table 1 provides the demographics of the sample.

Table 1. Details of the interviewees.

\section{[Please insert Table 1 here]}

The study consisted of a total of 15 interviews providing sufficient basis for analysing MRO inventory challenges in the case company. The sample should prove adequate because the samples to be utilised in qualitative research are discretionary to the researcher. The research objects, although few in number, were studied thoroughly. The emphasis was on the quality of the input material while the size of the sample must be adequate for the type of analysis and interpretation (Patton, 2002). No standard methods exist for determining sample size in qualitative research (Moore, 2000), but the size depends on what the researcher wants to know, the purpose of the enquiry, usefulness of the date, its credibility, and resources (Patton, 1990). Patton refers to reasonable coverage of the phenomenon given the purpose of the study (Patton, 1990). Various examples of rather small sample sizes also exist (e.g. Trautmann et al., 2009). Interviews were chosen as a primary data gathering method due to their insightfulness, the possibility to gain rich data, and the possibility to focus directly on the study topic (Yin, 2003). The aim of the interviews was to identify and document all the challenges related to MRO inventory. After a brief analysis of the data, the challenges were rated by a small focus group that was carefully selected based on a broad knowledge of the subject. An evaluation matrix was sent to five people: an inventory supervisor, a stockman, a head of electric automation maintenance, an electric automation planning engineer, and a mechanical planning engineering. Beyond this, company representatives were committed to the development process by organising a brainstorming session. The titles of the included persons were inventory supervisor, stockman, both mechanical and electric automation planning engineers, head of mechanical maintenance, and system specialist. The aim of the brainstorm was to develop and evaluate different solutions to challenges faced in spare 
part inventory management. Another aim was to involve company representatives as part of the project and thus create solutions that fit with company practices in the best possible manner. The session lasted approximately half a day.

The semi-structured interviews (Merton et al., 1990) were conducted in a qualitative manner and were conducted more or less informally, allowing the interviewees to freely explain and clarify the discussed issues. The interviews were carefully prepared, and open-ended survey questions were sent to interviewees in advance. The interviews were recorded and transcribed to enable thorough analyses. The researcher also took notes about key points during the interview. Notes were revised soon after the interviews to enable later interpretation. Each studied department was analysed to obtain department specific understanding about the studied issues. The data was analysed by grouping challenges relating to spare part management under the four main themes according to the theoretical framework created earlier.

In addition to interviews, supporting data was gathered by studying company information systems: in particular inventory related issues in ERP were carefully studied and analysed. In this sense, the quality of data was the most analysed research subject. Observation was also utilised if the understanding of a phenomenon was required; it was exploited, for example, to understand daily stocking operations. Inventory related documents, such as reports, were studied in order to increase the reliability of the analysis.

\subsection{The case company}

The case company is one of the largest urban energy companies in Finland with approximately $1100 \mathrm{GWh}$ of electric power and $1600 \mathrm{GWh}$ of heat energy generating capacity. Annual energy production capacity is approximately $2700 \mathrm{GWh}$. The annual turnover of the company is roughly 300 million euros. The company produces and sells both electrical power and district heating. In addition, it provides natural gas for its industrial customers. The company's two plants are powered by burning coal, natural gas, and waste. It is also involved in partnerships that produce electric power by exploiting different energy sources such as wind power and nuclear power. A company subsidiary is responsible for the power distribution network in the local area. The company is also involved in energy contracting, covering communal technologies, planning, and other services through a partnership. The company is funded by selling energy to its customers and by issuing debt; hence, it is not funded by tax euros. The company is owned by two surrounding cities. The case company has a strategic target to be an even more environmentally friendly energy company in the future; furthermore, they emphasise the importance of undisturbed energy distribution and promote themselves as an energy company that provides suitable solutions to customers. Electricity is sold nationally to industrial customers and for domestic use in the local and nearby areas. District heating is provided mainly to local customers. Two power plants located within the city limits form the foundation of the company's co-production of heat and electricity. One of these plants is a state-of-the-art waste to energy plant. These plants are responsible for about half of the company's electricity production; the other half originates from partnerships involving several sites in Norway and south west Finland.

According to the case company, they have three main business processes: energy production, energy supply, and sales and marketing. However, the case company defines the MRO inventory concept as a very significant support function for the energy production and supply processes. The company has two plants, which are located within the same municipality. The older one is powered mainly by coal and the newer one is powered mainly by waste. Due to the difference in energy production methods, the plants have mostly dissimilar equipment. Both plants have their own MRO inventory and 
maintenance organisation to maintain the facilities. These inventories also serve the power distribution network business the company is involved in. The cooperation between these two MRO inventories has been quite limited. MRO inventories to maintain electric power transmission lines are decentralised and heat power distribution maintenance is managed so that there is no need to have inventories: materials are ordered directly to the site once a failure has been identified. In the case of emergency situations, a few spares are stored for the maintenance of heat power distribution. However, these spares comprise only an insignificant share of the whole MRO inventory value. Thus, this study focuses only on the MRO inventories that maintain energy production in the two plants. As a main information system, the company uses an enterprise resource system that has a maintenance module amongst other features. An extranet solution also exists for information sharing. The case company shares data and information between users and departments via these information systems.

The company inventory is worth millions of euros, yet only $17 \%$ of the titles in inventory have been given value due to a previous practice of not valuing inventory in the ERP system. Budget control is applied on inventory procurement, and roughly 300000 items are procured annually. The company inventory includes a significant number of inventory items, yet there are challenges with the data quality of inventory items causing some overlap and unnecessary entries in the ERP system.

The production manager is the head of the inventory concept in the company. The inventory supervisor is the subordinate of the production manager but is present as a manager for the rest of the inventory personnel. He/she takes control over day-to-day operations and short-term planning, particularly in the newer plant. Since the company has two MRO inventories, there is a specialist that takes control and is responsible for the inventory of the older plant. Procurement is decentralised, meaning that planning engineers acquire special and strategic spare parts and stockmen acquire standard and bulk material while the procurement department takes control over contractual issues. 


\section{RESULTS AND ANALYSIS}

The findings indicate significant challenges for MRO inventory control in the studied company. Pitfalls were found in all four aspects present in the literature, including supplier management, material management, information system management, and spare part inventory management. The most significant observation was a great variation between employed practices, indicating immature management practices.

\subsection{MRO inventory management}

The findings indicate that one of the key challenges in MRO inventory control is the carelessness of spare part stocking. For example, the case company had not valued its MRO inventories until the newer plant was built a few years ago. However, this decision has not been applied properly in practice since only approximately $17 \%$ of all stocked spare parts and materials have a known value. The organisational culture emphasises and supports the high utilisation rate of plants, and thus maintenance staff have high service rate expectations. Furthermore, expectations have been raised regarding the undisturbed service ability of MRO inventories as illustrated by the following quote by a mechanical maintenance engineer: Once we [maintenance engineer] are facing stock-out during equipment breakdown and production down time increases, the production engineers are blaming us for the low utilisation rate and production losses. Irregularities in our service ability are simply not tolerated. On the other hand, no one is challenging us on inventory costs. Spare part stocking costs have not been identified nor are they perceived as insignificant because they are often compared to costs of production loss. The development of inventory costs is not properly understood, and thus stocking decisions have not always been economic. Inventory costs have been experienced as inevitable costs that are needed to support production. There are no existing methods for measuring MRO inventory operations, and reporting to senior management is lacking. Hence, senior management has a quite poor understanding of the present state of MRO inventories; for example, the present value and trend of inventories are not known, as illustrated by a quote from production manager: I [production manager] have to admit that I do not really have any clue about the present state of inventories or what the trend is. For as long as I remember, nobody has ever paid attention to inventories. Targets for spare part stocking are also absent. Since there are no targets in place and processes are not documented or modelled, the variation in current practices is substantial.

The analysed company has an organisation for inventory management, which takes control over day-to-day operations. However, there is no dedicated person to take control of long-term planning and development or who is responsible for reporting. In fact, MRO inventory control has been strongly maintenance-oriented. The inventory supervisor is heavily focused on daily operations and does not have enough time to coordinate MRO inventory operations at a business level, as the following quote indicates: I [inventory supervisor] am responsible for the whole inventory concept but still need to take control over daily operations of the newer plant. Further, there is a way too huge 'chasm' between the production manager and me. His hands are tied with top-management issues, and thus he has no time to coordinate our operations. He barely has enough time to accept our purchasing requests. Stocking decisions are based on production targets without any consideration of inventory costs. The current practices and methods are more or less individual and their validity depends heavily on one's expertise. 
There were targets for development in every area. Individuals might have solutions to these challenges faced in MRO inventory control, but these solutions were not applied in practice since solution owners were not usually eager to promote inventory practices. In general, the cooperation between different departments and individuals was experienced as quite poor. The challenges faced by management reflect the challenges in MRO inventory sub-processes that are presented in the following sections.

Finding 1: Effective MRO inventory operations cannot be carried out sufficiently if treated in isolation or without adequate wider focus on inventory practices.

\subsection{Material management}

Part coding is not tightly controlled in the analysed organisation; thus, almost every employer is allowed to create items in the ERP system. According to interviewees, coding cannot be restricted to a few people since this would decrease the efficiency of operations. There are general instructions in the extranet as to how to create new items into the ERP system and what information should be included. Nevertheless, not all interviewees were aware of the instructions. In addition, the instructions have changed several times but users have not been properly informed. In addition, some interviewees do not find the instructions very usable, and thus they apply their own practices. The head of the mechanical engineering maintenance department underlined the importance of information sharing as follows: At the implementation of ERP the instructions were updated several times. First, they [system specialists] informed us [maintenance planning engineers] about the updates but after a few iterations they did not inform us anymore. In addition, most of us cannot find the instructions in our extranet.

Planning engineers or stockmen do not have any common model or method to classify spare parts. In spite of the fact that there were some relevant methods employed amongst the interviewees, they emphasised their own experience when making storage decisions. Decisions whether to store in company storage or not are mostly based on the need to find a trade-off between inventory holding costs and potential production loss costs. Even though buyers are trying to minimise inventory holding costs, the ability to support production process is often seen as a much greater factor in the decision making process. Since there is no collectively created model to classify spare parts and to make storage decisions, a buyer cannot justify the decision of not storing a spare that is not so critical for the company. On the other hand, from a management viewpoint, it is hard to control stocking decisions because of the lack of a common way to act, particularly in relation to changes.

Demand forecasting is based on hypotheses and estimations about failure rates since theoretical models do not exist. The practices employed have a great variance because some exploit historic data on consumption rates while others justify their decisions by exploiting other information sources such as their own experience. However, historic data about consumption and orders are not always valid because repair reports are not properly completed, and thus historic data is not usable. Sometimes forecasts are based on failure rates given by the supplier, but these do not consider the amount of similar installed equipment or the operational intensity. Hence, demand forecasting is quite inaccurate and increases uncertainty.

Establishing re-order points and quantities is a very unclear issue in the analysed company, as illustrated by the following quote from a mechanical planning engineer: Establishing a re-order point? I [planning engineer] was asked by my boss [the head of mechanical maintenance] to set re-order points for the materials that I acquire but I was not instructed at all. I just put some made up some figures into ERP [system] since I had 
no idea how to approach the issue. The employees do not properly understand the principles of theoretical models on how to calculate the parameters. In addition, the capabilities of exploiting ERP are somewhat inadequate. There are existing instructions for establishing re-order points and economic order quantities, but users are not aware of these, or they are not willing to study and obey them. The responsibility issue of who acquires materials that belong to automated ordering processes is also unclear.

Finding 2: Material management alone is too narrow a perspective on developing MRO inventory operations, and a wider focus and steering is required.

\subsection{Supplier management}

The size of the analysed company sets some restrictions on adopting best practices for supplier management as annual investments on spare parts are relatively low in terms of single suppliers. Acquisitions made by planning engineers divide into several different suppliers as spare part selection is rather large and no one single supplier exists who could supply most of the materials. However, according to interviewees, the wide diversity of suppliers is mostly due to unawareness of alternative spares, and thus this problem concerns the newer plant in particular. Hence, the findings indicate that there are opportunities to reduce the number of suppliers.

Supplier management is based on blanket agreements that have been drawn up by the procurement department, by planning engineers, or by stockmen. Buyers feel that they have not been able to adequately influence the content of these agreements and they are somewhat dissatisfied. On the other hand, the awareness of agreements and their content is poor. The procurement department was not aware of this problem and was puzzled by the dispersion of acquisitions, as illustrated by the following quote from the head of the procurement department: Buyers are old-fashioned with their acquisition habits. They prefer individual relationships with suppliers instead of blanket agreements. They do not see the overall benefits gained by centralising acquisitions. It is quite frustrating to negotiate with suppliers since nobody really exploits them.

The procurement department does not seem to analyse how suppliers and acquisitions group according to material type and spending. Hence, there is no understanding about which are the most important suppliers, and resources for supplier management cannot be allocated in the most efficient manner. Even though the company representatives believe that the size of the budget is too small to negotiate about different supply strategies, there might be opportunities to do this by centralising acquisitions.

Along with narrowing the diversity of supplier selection and improving cooperation with suppliers, another target for development is to study the current practice of vendor managed inventory (VMI). Currently, the material selection is too narrow to do this because a significant share of bulk and standard material is acquired outside of VMI agreements. This keeps stockmen busy because of the need to do recurring ordering work. It also causes extra work in accounting. In addition, the company owns material within these agreements, meaning that there is capital committed. The analysed company has not assessed the benefits to be gained in unit prices compared to committed capital costs. The experienced inventory supervisor became enthusiastic once he was asked about current VMI practices: I [inventory supervisor] do not really know why we own the material included in VMI. In fact, I do not even know what and how much material the agreement includes. This is definitely an issue that should be reviewed.

Finding 3: Supplier management requires both a focused approach towards third parties and adequate internal cooperation in order to develop MRO inventory operations. 


\subsection{Information system management}

Without exception, interviewees brought up the poor quality of inventory related data in the ERP system. For example, findings reveal that less than $50 \%$ of existing data and $77 \%$ of new data in ERP passes the requirements set by existing instructions. The situation has a negative effect on almost every spare part management process. Hence, data quality, a basic element for spare part management, has to be get on track before any other MRO stocking sub-process can be improved. Poor data quality increases the possibility of creating duplicate items in ERP and also causes extra work for both planning engineers and stockmen. They cannot easily find the spares they need and the information becomes unusable in practice. In particular, the lack of information about the equipment tree it refers to can cause significant challenges in other spare part management processes. The experienced head of electrical automation maintenance engineering underlined the importance of data quality: Data quality is the most important development target since it has impact on everything that we [planning engineers] do. The present state of data quality is way too poor to enable the development of other inventory control methods.

New spare part related data emerges alongside ordering, planning, and maintenance processes, albeit the main source is the ordering process. As mentioned earlier, no data governance organisation exists to be responsible for the new data. Even though users are willing to improve data quality, it has not received enough emphasis from company management. There have been some data improvement projects, but their results have never met targets. Based on the statement by the head of mechanical maintenance, this was the result of unsuccessful project organisation as users were not sufficiently involved.

Considering material management, user guidance has failed in both significant 'data manufacturing' processes: establishing re-order points and quantities (i.e. ordering process automation), and part coding. There have not been practices to control data quality, and users have not received any feedback about their behaviour. The findings indicate that there has been a chasm between users and IT governance. This appears to explain why the needs of users have not been identified. The analysed company is lacking a common language as to how inventory related data should be created, responsibility issues are unclear, and there are no practices to control and measure the quality of data.

According to interviewees, there would not be significant benefits available from the involvement of supply chains in ERP due to the wide diversity of suppliers. Once acquisitions could be better concentrated, it might be an opportunity with the most significant suppliers. The poor quality of data and inadequacy in inventory management practices seems to make supplier integration impossible. According to the director of the procurement department, they are aiming towards better coordination of suppliers. More information about suppliers is going to be collected by requesting/requiring buyers to follow best practice. According to the head of the procurement department, current practices do not support supplier analysis. In this sense, supplier integration into information systems seems to provide significant benefits.

Finding 4: Information system management has a key role in successfully developing MRO inventory operations, particular emphasis being required on acknowledging users' needs and data quality. A wider perspective is necessary.

Finding 5: Considering business processes is important for successfully developing MRO inventory operations when actions relate to material management, supplier management, or information system management. 
Finding 6: Information system management may enable re-engineering of the entire process of MRO inventory development.

\subsection{Challenges in the analysed company}

The current state analysis of the company revealed that MRO inventory management had not been on the agenda of the company management - it is in its infancy overall (Figure 3 ). Inventory management focuses on daily operational activities, whereas any long-run planning or development is lacking. This in turn results in unorthodox and risky operations and processes. Development activities should be initiated from long-run planning rather than optimising smaller inventory control activities as it seems that there is not enough consistent data and information available for development. The figure illustrates challenges faced that relate particularly to inventory management, material management, supply management, and information system management. Each of the challenges affect operations in their own way.

\section{[Please insert Figure 3 here]}

Figure 3. Synthesis of the challenges in the case company.

Table 2 further details the challenges together with presenting potential solutions. The challenges are presented with the identified cause and the effect on the operations as well as indicating the departments influenced by each challenge. The potential solutions are based on interviewees' views on how to potentially address the challenges.

Finding 7: Developing MRO inventory operations revolves around the potential success of solving existing challenges with an adequately wide perspective. 
Table 2. Challenges faced by MRO operations \& potential solutions.

[Please insert Table 2 here] 


\section{DISCUSSION}

\subsection{Creation of MRO inventory management development process framework}

The literature presents different best practices for approaches to MRO inventory reduction and development operations, including supplier management, material management, information system management, and BPM as an umbrella concept (e.g. Bailey and Helms, 2007; Cavalieri et al., 2008; Huiskonen, 2001; Lee and Dale, 1998; Molenaers et al., 2012) and discusses the importance of spare part inventory management (e.g. Aberdeen, 2006; Bailey and Helms, 2007; Kennedy et al., 2002, Mehotra et al., 2001; Sarker and Hague, 2000). Most authors present specific methods to improve and develop MRO inventory processes. This study provides a new contribution to the literature by exploiting these different approaches to analysing the case company's spare part management as a whole business process, trying to identify pitfalls and targets for development. Results of the study indicate that the present state of the MRO inventory requires development and further consideration beyond focus on mere on day-to-day operations. The analysed company is struggling with inventory management practices, the most notable flaws appearing to lie in the management of the business process.

Targets for development were generated by comparing current practices with literature based best practices. Results were validated through an organised brainstorming session involving key persons from different departments to create the most practical and beneficial solutions. A framework was devised for MRO inventory management development processes and was assessed by carefully selected persons. The framework is presented in following section.

\subsection{Framework for MRO inventory management}

The key target for development is the re-engineering of inventory management system. This enables adopting and exploiting best practices in material management, supplier management, and information system management (Bailey and Helms, 2007; Cavalieri et al., 2008; Huiskonen, 2001; Lee and Dale, 1998; Otto et al., 2007; Yingling, 1997). The need for development was identified as involving all the main processes of MRO inventory management: supplier management, material management, and information system management. The results indicate that having the MRO inventory management organisation supporting day-to-day operations is not enough to enable long-term planning, development, or active reporting about the state of the inventory. This study is in line with Lee and Dale (1998) and DeToro and McCabe (1997) in that when reengineering the management organisation, the importance of information flows bottomup and top-down and cross-functionality should be emphasised. Most challenges faced in inventory management can be attributed to lack of cooperation. In line with Lee and Dale (1998) and Yingling (1997), there is a need to form an inventory-oriented development team that occasionally meets and discusses development needs for spare part stocking in the light of performance measures. Another aim of the development team would be finding the best way to achieve the targets. In the event that there is no named person in charge of the MRO inventory concept, establishing a position of business controller to coordinate and develop the business process as a whole and to report actively to senior management about the present state of MRO inventory would be recommended. 
Overall, this study provides new perspectives to the literature by pointing out how it is essential to recognise MRO stocking as a business process that requires continuous assessment and development. Senior management must enable the development process by allocating required resources, setting targets for development, and emphasising the required change in organisational culture.

In line with Cavalieri et al. (2008), this study recognises that unambiguous methods and tools for material management are needed to take into account the requirements of different parties. Practices can be fragmented - thus it can be tough to coordinate spare part management processes. Rather, the principles of material management theory should be applied, for instance when establishing re-order points or forecasting demand, particularly if current practices do not exploit them (e.g. Cavalieri et al., 2008; Costa and Silver, 1995; Dekker and Porras, 2008; Molenaers et al., 2012; Ruiz-Torres and Mahmoodi, 2010; Wang and Zhang, 2008 ). It is notable that the part coding process and establishing a process for re-order points should be modelled and documented with easily available instructions. In addition, any confusion with regards to ERP system exploitation must be eliminated. In line with Cavalier et al. (2008) and Hammer (2002), this study notes also that the quality of these processes must be measured and controlled to enable development when needed.

Considering the spare part acquisition process, creating an operational model to classify spares according to their criticality, value, demand pattern, and logistics characteristics may prove beneficial. This study is in line with Huiskonen (2001) and Molenaers et al. (2012) in that this might also assist in choosing a suitable supply strategy. Commonly agreed practices may prevent conflicts between departments particularly if there are inconsistencies in requirements. Supplier management can be developed by enhancing the cooperation between procurement and buyers, enabling the requirements of different parties to be mutually taken into account. Furthermore, new opportunities may rise for analysing suppliers and centralising acquisitions. In addition, agreements such as VMI are seen as worthy of reviewing with regards to ownership issues and possibilities of cutting costs.

In line with Otto et al. (2007) and Wende (2007), this study recognises how information system management may require a governance model, from the spare part management viewpoint, to emphasise responsibility over quality of inventory and spare part related data and to provide feedback for users both collectively and individually. Variety in part coding practices can leads to poor quality of items in ERP systems if the process is not controlled. The enhancement of data quality is seen as the most important target for development due to the potential extra work and harm to the development of other spare part management processes. The quality of new data can be controlled by creating formal responsibilities. Existing data in ERP systems may also require data quality improvement projects involving both data users and system specialists. Figure 4 illustrates a framework for a potential MRO inventory management development process based on the findings of this study.

Finding 8: Focusing on development targets, particularly those derived from existing challenges, will most likely have a positive impact on spare part inventory operations, yet adequate indicators are necessary to measure the impact.

\section{[Please insert Figure 4 here]}

Figure 4. A potential framework for the MRO inventory management development process for capital intensive industries. 
Developing MRO inventory operations requires management to realise the need for development, whereas the development actions must improve managers' understanding about the inventory. It is possible to develop operations that have clearly set targets. However, in order to develop truly effective MRO inventory, it is vital to perceive the big picture so that the development actions will be effective. This applies to setting goals and working with indicators, and highlights the importance of understanding the framework and its parts. The results indicate that addressing relevant existing challenges can be a starting point for target setting. The development actions must involve measures to support management understanding, yet management must also support the development. The results also indicate that supplier management, material management, and information system management are not individually sufficient to develop spare part inventory operations, but cooperation and wide-based development is required. Hence, attention must be paid to cooperation enhancement. Assigning responsibilities in relation to MRO inventory processes and forming the necessary development teams are necessary in order to enhance cooperation. Departmental and individual commitment are also needed. The results indicate how information system management has a key role in developing MRO inventory operations. Development actions involving user related considerations and data quality are of vital importance. Material management must develop and revise the existing practices relating to spare part classification, demand forecasting, and establishment of re-order points and quantities. Similarly, supplier management must develop and revise the existing practices relating to characteristics of spare part logistics, necessary strategies, and supplier coordination and control. As the results indicate, careful consideration of business processes may be necessary for successful development of MRO inventory operations as, after all, the role of MRO inventory is to support the primary business. 


\section{CONCLUSIONS}

MRO inventory management differs from other production related inventories, such as WIP and finished product inventories, in a many ways. The operational environment is characterised by great uncertainty, low and erratic demand, complex causalities, and enormous variety in characteristics of spare parts. Due to these challenges, traditional inventory management methods cannot be directly applied as they may lead to significant errors. However, investments in spare part inventories may be remarkably high, hence there are pressures to reduce inventories to cut costs. This study analyses opportunities to reduce MRO inventories by considering improvements in the efficiency of operations.

This study identifies four approaches to developing MRO inventory operations and reducing inventory, namely: material management, supplier management, information system management, and BPM. The last of these is seen as an umbrella concept for the other three inventory management processes. Material management, supplier management and information system management are tightly connected to each other, and decisions made concerning one of these have an effect on the others. Material management regarding spare part management consists of part coding, part classification, demand forecasting, and establishing re-order points and quantities. Similarly, supplier management consists of identifying network structures, strategy development for spare part logistics, and supplier coordination and control. Information system management relates to automation of ordering processes, data quality control, and supplier integration into information systems.

The analysis results indicate that MRO inventory management required development in the analysed company. Pitfalls were found in all areas even though some relevant practices were implemented. The most significant flaw concerned the management of spare part processes as a business process since most of the identified challenges resulted from poor coordination and organisation of the practices. From a management viewpoint, it could be said that MRO inventory is a process that 'just took place'. Material management suffers from the dispersion of employed practices and methods. Valid tools and methods may already exist but to be beneficial they must be collectively agreed. Noteworthy also is whether the tools exploit any theoretical principles. Supplier management practices were mainly based on blanket agreements. However, these agreements were found relatively worthless as they did not meet the buyers' preferences. In addition, the awareness of these agreements was rather poor. Practices for conducting analyses on suppliers or spending were also lacking, and thus different supply strategies were not assessed. In addition, information system management suffered from lack of data quality governance. The data quality was found to be poor and uncontrolled. Users were not aware of basic instructions, or were not willing to obey rules for various reasons. Since the data quality was poor the benefits gained from automated ordering process were lost. Due to the process environment and scale of the business, results indicated that there were not significant benefits achievable concerning supply chain integration in information systems.

Most challenges faced in spare part inventory management seem to be able to be solved by forming a proper governance model for the MRO inventory concept. Challenges faced in spare part management practices were mostly due to poor information flows between departments. There also seemed to be needs arising for requirements engineering and management of operations. Therefore, nominating a concept leader to coordinate and design MRO inventory as a business process was seen as a partial solution to achieving targets. In addition, a development team involving key personnel from inventory related departments might prove beneficial. Monthly meetings seem to be the correct platform for development plans and other spare part management issues. In the 
event that employed inventory management practices are somewhat basic, it is not meaningful to adopt the most advanced methods for material management or for supplier management, but rather to select functional methods and tools. These can then be developed step-by-step through monthly meetings. Data quality improvement can take place by forming a data quality governance model to control 'data manufacturing' processes by occasionally checking the quality of new data. In general, the spare part management processes need to be measured and the results analysed to identify development needs.

Managers can benefit from the results of this study by understanding the importance of management activities on MRO spare part inventories. Focusing just on limited spare part controlling activities is not enough to reach the desired targets. Rather, spare part stocking should be considered as a business process. Thus, successful spare part inventory management may require the adoption of BPM methods which enable continuous development of inventory controlling practices. It is highly recommended to involve senior management once the need for inventory operations development is identified to ensure the ability to allocate the required resources and to execute organisational-wide cultural change.

The limitations of this study include the practical implementation of the analysed company's MRO inventory reduction being lacking due to tight schedules and inadequate resources by the company. In addition, achievable financial benefits could not be presented as current practices do not provide enough information to present reliable figures. Hence, recommend future studies could include comprehensive research on the implementation of the results presented in this study. It would also be interesting to analyse how MRO inventories are managed as a business process in general, including for example requirements engineering and process management. This as the managerial perspective is lacking in this research area. 


\section{REFERENCES}

Aberdeen Group (2006) The asset management benchmark report: moving toward zero downtime [Online]. Aberdeen Group. Available: http://www.aberdeen.com. [Accessed: 20 July 2016].

Armenzoni, M., Montanari, R., Vignali, G., Bottani, E., Ferretti, G., Solari, F. and Rinaldi, M. (2015) 'An integrated approach for demand forecasting and inventory management optimisation of spare parts', International Journal of Simulation and Process Modelling, Vol. 10, No. 3, pp.223-240.

Armistead, C. and Mapes, J. (1993) "The Impact of Supply Chain Integration on Operating Performance", Logistics Information Management, Vol. 6, No. 4, pp.9-14.

Bailey, G.J. and Helms, M.M. (2007) "MRO inventory reduction - challenges and management: a case study of the Tennessee Valley Authority", Production Planning \& Control, Vol. 18, No. 3, pp. 261-270.

Baldassarre, F., Ricciardi, F. and Campo, R. (2016) "Business Process Management As a Strategy to Implement Organizational Innovation", Journal of Emerging Trends in Marketing and Management, Vol 1, No. 1, pp.292-301.

Braglia, M., Grassi, A., Montanari, R. (2004) "Multi-attribute classification method for spare parts inventory management", Journal of Quality in Maintenance Engineering, Vol. 10, No. 1, pp.55-65.

Cardamone, P.J. (1996) Critical spares inventory management. Transactions of AACE International, MAT21-MAT24. ISBN: 1885517041.

Cavalieri, S., Garetti, M., Macchi, M. and Pinto, R. (2008) "A decision-making framework for managing maintenance spare parts", Production Planning \& Control, vol. 19, No. 4, pp. 379396.

Costa, D. and Silver, E. (1995) "Service and inventory level implications of a particular simple method of establishing the reorder point", Information Systems and Operational Research. Vol. 33, No. 2, pp. 133-144.

Dekker, R. and Porras, E. (2008) "An inventory control system for spare part at a refinery: An empirical comparison of different re-order point methods", European Journal of Operational Research, Vol. 194, No. 1, pp. 101-132.

DeToro, I. and McCabe, T. (1997) "How to stay flexible and elude fads", Quality Progress, Vol. 30, No. 3, pp. 55-60.

Eaves, A.H. and Kingsman, B.G. (2004) "Forecasting for the ordering and stock-holding of spare parts", Journal of the Operational Research Society, Vol. 55, No. 4, pp. 431-437.

Eisenhardt, K. (1989) "Building theories from case study research", Academy of Management Review, Vol. 14, No. 4, pp. 532-550.

Gunasekaran, A. and Ngai E.W.T. (2004) "Information systems in supply chain integration and management", European Journal of Operational Research, Vol. 159, No.2, pp. 269-295.

Hadidi, L.A., Al-Turki, U.M. and Rahim, A. (2012) 'Integrated models in production planning and scheduling, maintenance and quality: a review', International Journal of Industrial and Systems Engineering, Vol. 10, No. 1, pp. 21-50.

Hammer, M. (2002) "Process management and the future of Six Sigma", MIT Sloan management review, Vol. 43, No. 2, pp. 26-32.

Harrington, H.J. (1995) Total Improvement Management - The Next Generation in Performance Improvement, McGraw-Hill, New York, NY.

Huiskonen, J. (2001) "Maintenance spare parts logistics: Special characteristics and strategic choices", International Journal of Production Economics, Vol. 71, pp. 125-133.

Jajimoggala, S., Rao, V.V.S.K. and Beela, S. (2012) "Spare parts criticality evaluation using hybrid multiple criteria decision making technique", International Journal of Information and Decision Sciences, Vol. 4, No.4, pp.350-370.

Kang, Y. and Gershwin, S.B. (2004) Information Inaccuracy in Inventory Systems - Stock Loss and Stockout. Doctoral thesis, Massachusetts Institute of Technology, Department of Mechanical Engineering. 
Kennedy, W.J., Patterson, J.W. and Fredendall, L.D. (2002) “An overview of recent literature on spare parts inventories", International Journal of Production Economics, Vol. 76, No. 1, pp. 201-215

Klein Haneveld, W.K. and Teunter R.H. (1997) "Optimal provisioning strategies for slow moving spare parts with small lead times", Journal of the Operational Research Society, Vol. 48, No. 2, pp.184-194.

Lau, H.C., Song, H., See, C.T. and Cheng, S.Y. (2006) "Evaluation of time-varying availability in multi-echelon spare parts systems with passivation", European Journal of Operational Research, Vol. 170, No. 1, pp. 91-105.

Lee, R.G. and Dale, B.G. (1998) "Business process management: a review and evaluation", Business Process Management Journal, vol. 4, No. 3, pp. 214-225.

Mahmood, W.H.W., Rahman, M.N.A., Deros, B.M. and Mazli, H. (2011) "Maintenance management system for upstream operations in oil and gas industry: a case study", International Journal of Industrial and Systems Engineering, Vol. 9, No. 3, pp. 317-329.

Mehrotra, A., Natraj, N.R. and Trick, M.A. (2001) "Consolidating maintenance spares", Computational Optimization and Applications, Vol. 18, No. 3, pp. 251-272.

Merton, R., Fiske, M. and Kendall, PP. (1990) The Focused Interview: A Manual of Problems and Procedures, 2nd ed. The Free Press, New York, NY.

Molenaers, A., Baets, H., Pintelon, L. and Wayenbergh, G. (2012) "Criticality classification of spare parts: A case study", International Journal of Production Economics, Vol. 140, No. 2, pp. 570-578.

Moore, J. (2000) “Determining sample size”, Qualitative Health Research, Vol. 10, No. 1, pp. 35.

Otto, B., Wende, K. Schmidt, A. and Osl, P. (2007) Towards a framework for corporate data quality management. $18^{\text {th }}$ Australian Conference on Information Systems, Vol, 109, pp. $916-$ 926.

Patton, M.Q. (1990) Qualitative evaluation and research methods, 2nd ed. Newbury Park, CA, Sage.

Patton, M.Q. (2002) Qualitative Research and Evaluation Methods, 3rd edition, Thousand Oaks, Sage Publications.

Pfohl, H.-C. and Ester, B. (1999) "Benchmarking for spare parts logistics", Benchmarking: An International Journal, Vol. 6, No. 1, pp.22-45.

Pingping, G. and Feng L. (2009) The Optimization and Application Model for Spare Parts Management Information System. IEEE (ed.) International Conference on Information Management, Innovation Management and Industrial Engineering, Vol. 3, pp. 46-49. ISBN: 978-0-7695-3876-1/09.

Pintelon, L., Du Preez, N. and Van Puyvelde, F. (1999) "Information technology: opportunities for maintenance management", Journal of Quality in Maintenance Engineering, Vol. 5, No. 1, pp. 9-24.

Ruiz-Torres, A.J. and Mahmoodi, F. (2010) "Safety stock determination based on parametric lead-time and demand information", International Journal of Production Research, Vol. 48, No. 10, pp. 2841-2857.

Ryan, P. (2001), "Suppliers' perspectives of lean operation and business-to-business relations from the periphery of an industrial market", Irish Marketing Review, Vol. 14 No. 1, pp. 5-14.

Sajadi, S.M. and Rad, M.F. (2016) 'Optimal production rate in production planning problem with simulation optimisation approach by simulated annealing', International Journal of Industrial and Systems Engineering, Vol. 22, No. 3, pp.262-280.

Sawhney, R., Kannan, S. and Li, X. (2009) "Developing a value stream map to evaluate breakdown maintenance operations", International Journal of Industrial and Systems Engineering, Vol. 4, No. 3, pp. 229-240.

Shamsaddini, R., Vesal, S.M. and Nawaser, K. (2015) "A new model for inventory items classification through integration of ABC-FUZZY and fuzzy analytic hierarchy process", International Journal of Industrial and Systems Engineering, Vol. 19, No. 2, pp. 239-261.

Silvola, R., Harkonen, J., Vilppola, O., Kropsu-Vehkapera, H. and Haapasalo, H. (2016) "Data quality assessment and improvement", International Journal of Business Information Systems, Vol. 22, No. 1, pp. 62-81. 
Sleptchenko, A., Van der Heijden, M. and Van Harten, A. (2005) "Using repair priorities to reduce stock investment in spare part networks", European Journal of Operational Research, Vol. 163, No. 3, pp.733-750.

Stratman, S. (2005) "Inventory state of mind: no pain, no gain (Part 2)". Construction Distribution, Vol. 8, No. 3, pp. 54-56.

Trautmann, G., Turkulainen, V., Hartmann, E. and Bals, L. (2009) "Integration in the global sourcing organization - an information processing perspective", Journal of Supply Chain Management, Vol. 45, No. 2, pp.57-74.

Tucci, M. and Bettini, G. (2006) Methods and tools for the reliability engineering: a plant maintenance perspective. Proceedings of the $2^{\text {nd }}$ Maintenance Management, MM2006, Italy: Sorrento.

Trkman, P. (2010) "The critical success factors of business process management", International Journal of Information Management, vol. 30, No. 2, pp.125-134.

van Houtum, G.-J. and Kranenburg, M. (2015) Spare Parts Inventory Control under System Availability Constraints. International series in operations research \& Science, Springer.

Vaughan, T.S. (2005) "Failure replacement and preventive maintenance spare parts ordering policy", European Journal of Operational Research, Vol. 163, No. 3, pp. 733-750.

Wang, W. and Syntetos A.A. (2011) "Spare parts demand: Linking forecasting to equipment maintenance" Transportation Research Part E: Logistics and Transportation Review, Vol. 47, No. 6, pp. 1194-1209.

Wang, Z. and Zhang, L. (2008) Nonparametric Statistic and Stochastic Optimization for Optimal Order Point Under Limit Capacity. Wireless Communication, Networking and Mobile Computing. $4^{\text {th }}$ International Conference. Dalian. pp. 1-4.

Wende, K. (2007) A Model for Data Governance - Organising Accountabilities for Data Quality Management. $18^{\text {th }}$ Australian Conference on Information Systems, Vol. 80, ppp. 417-425

Wen-Yong, Z., Ying, X. and Bing, S. (2011) "Study on spare parts inventory control by quantitative analysis in the environment of ERP system", Business Management and Electronic Information, IEEE, Vol. 5, pp. 259-263.

Yin, R. (2003) Case Study Research: Design and Methods, 3rd Edition, Sage Publications.

Yingling, R. (1997) "How to manage key business processes", Quality Progress, Vol. 30, No. 4, pp. 107-110.

Younis, K., Turner, C.J. and Tiwari, A. (2013) "Inventory reduction and management: a partner selection and inventory reduction study", International journal of Integrated Supply Management, Vol. 8, No. 4, pp.210-232.

Yu, G. (1997) "Robust economic order quantity models", European Journal of Operational Research, Vol. 100, No.3, pp.482-493.

Zairi, M. (1997) "Business process management: a boundary less approach to modern competitiveness", Business Process Management, Vol. 3, No.1, pp. 64-80.

Zeng, Y. and Wang, L. (2010) "A hybrid decision support system for slow moving spare parts joint replenishment: a case study in a nuclear power plant", International Journal of Computer Applications in Technology, Vol. 37, No. 3-4, pp.287-296. 
Appendix A. Interviews - current state

\section{Interviewee}

Name, department, background, tasks.

\section{Interview}

The interview is carried out as part of a study to develop spare part inventory functions. The aim is to describe potential avenues to decrease stock/control stock growth. The interview responses will be dealt with confidentially.

The respondents are asked to provide answers to their best ability and are allowed to explain and clarify the discussed issues as entities.

\section{Warehouse \& planning engineers}

\section{Material management}

How would you describe the material management processes of spare part inventory? The following questions link to material management processes in the literature. These are listed below the questions.

How does your company realise this process?

How important do you see this process and why?

How would you develop the process?

How does this process relate to other processes, departments, and persons?

What type of limitations does the process environment set?

- Itemisation of spare parts into information systems (Cavalieri et al., 2008; Bailey and Helms, 2007; Otto et al., 2007)

- Classifying spare parts (Huiskonen, 2001; Cavalieri et al., 2008; Bailey and Helms, 2007; Molenaers et al., 2012)

- Forecasting spare part consumption (Cavalieri et al., 2008; Wang and Syntetos, 2011)

- Setting order points for spare parts (Costa and Silver, 1995; Wang and Zhang, 2008)

\section{Supplier management}

How are suppliers managed?

How are different supplier and supply options compared and assessed?

How are supply costs compared to other costs?

What types of contractual agreements is the cooperation with suppliers based on?

What type of relationship does the company have to spare part suppliers (is the aim to centralise procurement, share information, etc.)?

How are spare part qualities (e.g. consumption, price, criticality, specific characteristics) acknowledged when considering procurement?

How would you develop the supplier management in your company? What benefits would be achieved?

How important do you see the development of supplier management?

\section{Managing information systems}

How do your information systems support spare part management in the company?

How are the benefits of information systems applied in your company?

How would you describe the quality of spare part data?

How is spare part specific data managed in the information system?

How is the information distributed to external actors such as suppliers? 
Are there any challenges that relate to the information systems supporting the management of spare parts?

How would you develop the information systems to support spare part management?

How important do you see information systems as an element of spare part management?

\section{Managing the warehouse process}

How would you describe the realisation of warehouse management? How does this relate to your position?

How are warehouse operations managed?

How is the storage of spare parts followed and assessed?

How do you see the follow-up and assessment to support both your and spare part management activities?

What type of indicators do you see as relevant for the follow up?

What type of opportunities the management give for developing spare part operations? (How does this relate to your post?)

How do you experience the cooperation between departments (financial, maintenance, warehouse, IT, quality control)?

How would you develop cooperation with other departments linked to spare part management?

\section{Production director}

How would you describe warehouse processes as a part of your company's business? What are the relationships and impact to other business processes?

How are the processes described and documented?

What is the main aim of spare part storage? What is the function?

What types of goals does the company have for spare part storage (level of storage, service levels, etc.)?

How are the requirements of different departments acknowledged when setting the goals for storage?

What type of organisation is responsible for spare part storage?

How is reporting organised? How do you follow, assess, and develop spare part operations and quality?

How do you measure spare part storage as a business process?

How do you ensure that industry best practices are followed?

What types of methods are utilised in managing spare part operations?

How do you ensure that processes are followed?

How should the company develop spare part storage? Which methods should be used in warehouse management? What types of indicators should be in place? What types of business benefits would be achieved?

What type of schedule has been set for the development project?

What type of support has top management been prepared to provide to implement the development actions?

How has informing employees and gaining their commitment been achieved?

Which departments are linked either directly or indirectly to managing spare part storage? Who are the key contact people in these departments?

\section{Financial administration}

What is the current value of warehouse?

How and on what basis are procurements acknowledged in bookkeeping?

How are procurement costs attributed to cost pools?

How is the removal of spare parts realised in a financial sense?

How does financial administration follow the value of the warehouse? 
How are warehouse costs estimated?

How are costs focused at the item level?

How would you develop the cooperation between financial administration and the warehouse?

How does the quality of warehouse item related information impact financial administration operations?

How does financial administration report warehouse financial matters?

What types of indicators are sensible for measuring stock value, taking the business into account?

\section{Maintenance operations}

What is the service ability of the warehouse in terms of spare parts?

What is the typical reason for inability to provide service? Which of these are the main issues with storage?

What types of parts or materials do challenges typically relate to?

Which of the stored materials support maintenance operations? How is part consumption acknowledged? How do quantities relate to consumption?

How is part consumption followed and forecasted? How is the warehouse informed?

How is the (in)ability of the warehouse to service needs reported?

How do maintenance operations utilise the information system with regards to storage and spare part specific information?

How can the warehouse's ability to service needs be improved from the perspective of maintenance operations? For example, can the use of the warehouse be improved?

\section{IT}

How has the creation of stock item data been described, documented, and organised?

How do you ensure that different departments are committed to following the practices of the information system?

What type of governance model is in place for stock data? How is the data tracked, monitored, and improved?

How could warehouse related data quality be improved?

What types of indicators exist for data quality in your company?

How could warehouse related data and information quality and usability be improved?

Do you see the integration of suppliers into your information system as a possible development; do you see it as improving cooperation? Why and how?

How are users trained on the information system? How are skills maintained? How would you describe users' skills with the information systems?

How was the information system implemented? Have the requirements set by the information system been delivered by the implementation?

What is the greatest challenge in relation to information system use and utilisation in relation to managing the warehouse process? How could this challenge be solved?

\section{Procurement manager}

How does your company manage suppliers?

How many different suppliers are there? How is procurement distributed amongst the suppliers?

What is the role of forwarding storage in the company? How could it be expanded or develop in fast moving materials?

Does the company have a particular procurement strategy? How does this impact spare part sourcing?

How are different suppliers and supply options compared?

How are supply related costs compared to other costs? 
What type of contractual practices is supplier cooperation based on?

What kind of relationship does the company have with its suppliers (has procurement been centralised, sharing information, etc.)? How are the contracts monitored and how is supplier commitment gained?

How are spare part qualities (e.g. consumption, price, production criticality, and rarity) considered when considering supply methods?

How would you further develop supplier management? What would the benefits be?

What types of indicators for procurement/supplier management are measured or could be measured?

How important do you see the development of supplier management? 


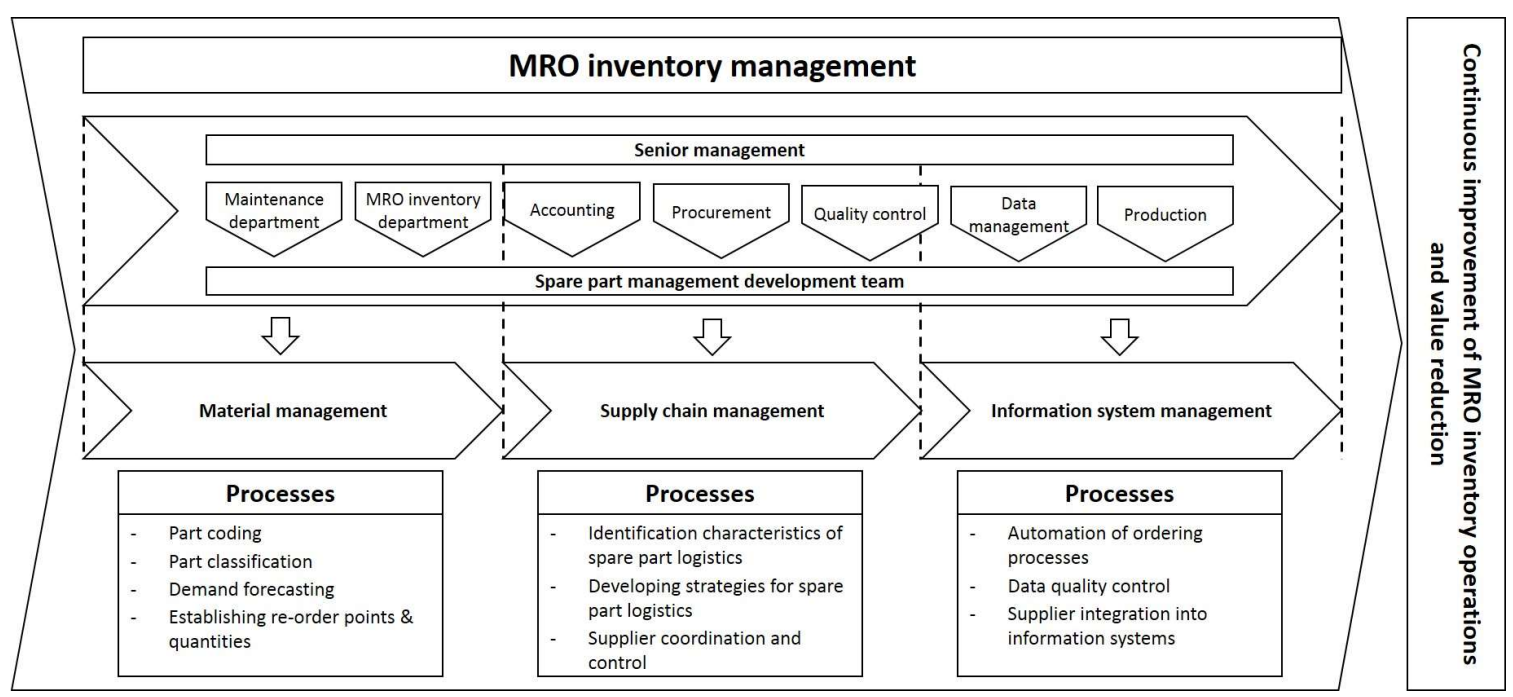

Figure 1. Theoretical framework for developing MRO inventory management.

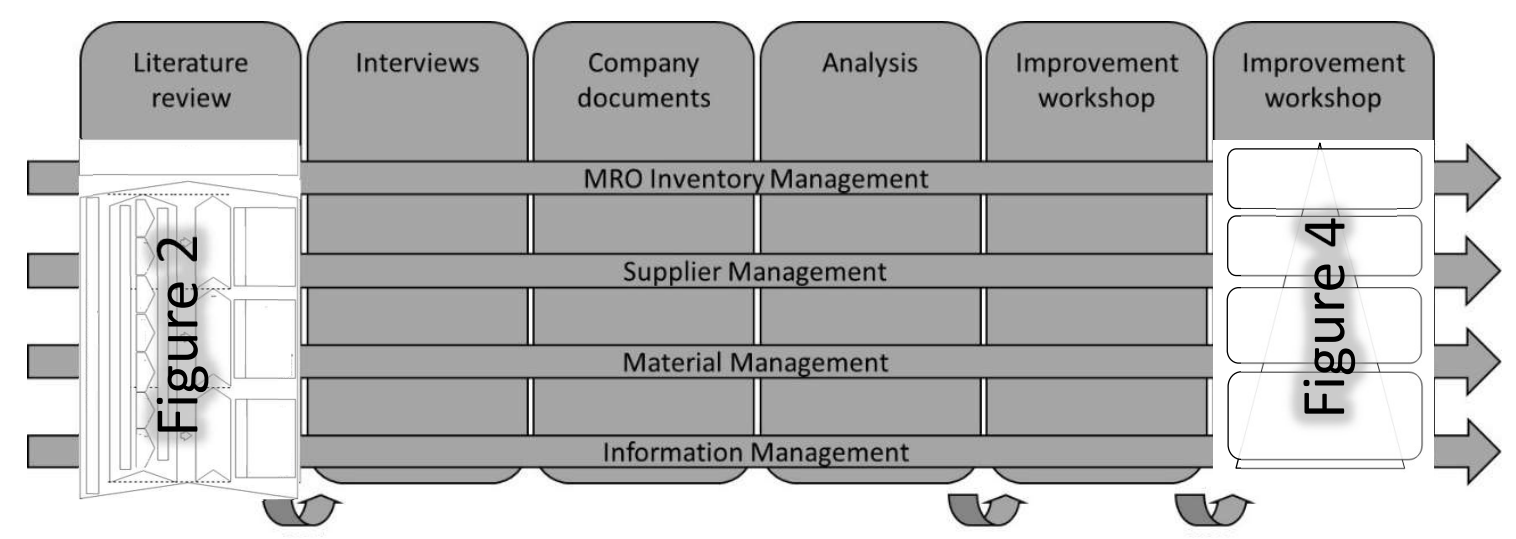

Figure 2. Research process. 
Table 1. Details of the interviewees.

\begin{tabular}{|c|c|c|c|}
\hline Title & Department & Degree & Experience/Knowledge \\
\hline Production director & $\begin{array}{l}\text { Production and heat } \\
\text { distribution }\end{array}$ & M.Sc, B.Sc & Extensive \\
\hline Inventory supervisor & Warehouse & Polytechnic & Extensive \\
\hline Stockman & Warehouse & Occupational training & Extensive \\
\hline Head of maintenance & $\begin{array}{l}\text { Mechanical } \\
\text { maintenance (site 1) }\end{array}$ & Polytechnic & Extensive \\
\hline Head of maintenance & $\begin{array}{l}\text { Mechanical } \\
\text { maintenance (site 2) }\end{array}$ & B.Sc & Extensive \\
\hline Planning engineer & $\begin{array}{l}\text { Mechanical } \\
\text { maintenance (site 2) }\end{array}$ & B.Sc & Good \\
\hline Planning engineer & $\begin{array}{l}\text { Mechanical } \\
\text { maintenance (site 2) }\end{array}$ & B.Sc & Good \\
\hline Head of maintenance & $\begin{array}{l}\text { Electrical automation } \\
\text { maintenance (site 2) }\end{array}$ & M.Sc & Extensive \\
\hline Planning engineer & $\begin{array}{l}\text { Electrical automation } \\
\text { maintenance (site } 2 \text { ) }\end{array}$ & B.Sc & Good \\
\hline Inventory supervisor & $\begin{array}{l}\text { Mechanical } \\
\text { maintenance } \\
\text { (operational) }\end{array}$ & Polytechnic & Extensive \\
\hline Procurement manager & Procurement & M.Sc & Extensive \\
\hline Business controller & $\begin{array}{l}\text { Financial } \\
\text { administration }\end{array}$ & M.Sc & Extensive \\
\hline System specialist & IT & M.Sc & Extensive \\
\hline Quality director & Quality control & M.Sc & Extensive \\
\hline Production manager & $\begin{array}{l}\text { Production and heat } \\
\text { distribution }\end{array}$ & B.Sc & Extensive \\
\hline
\end{tabular}

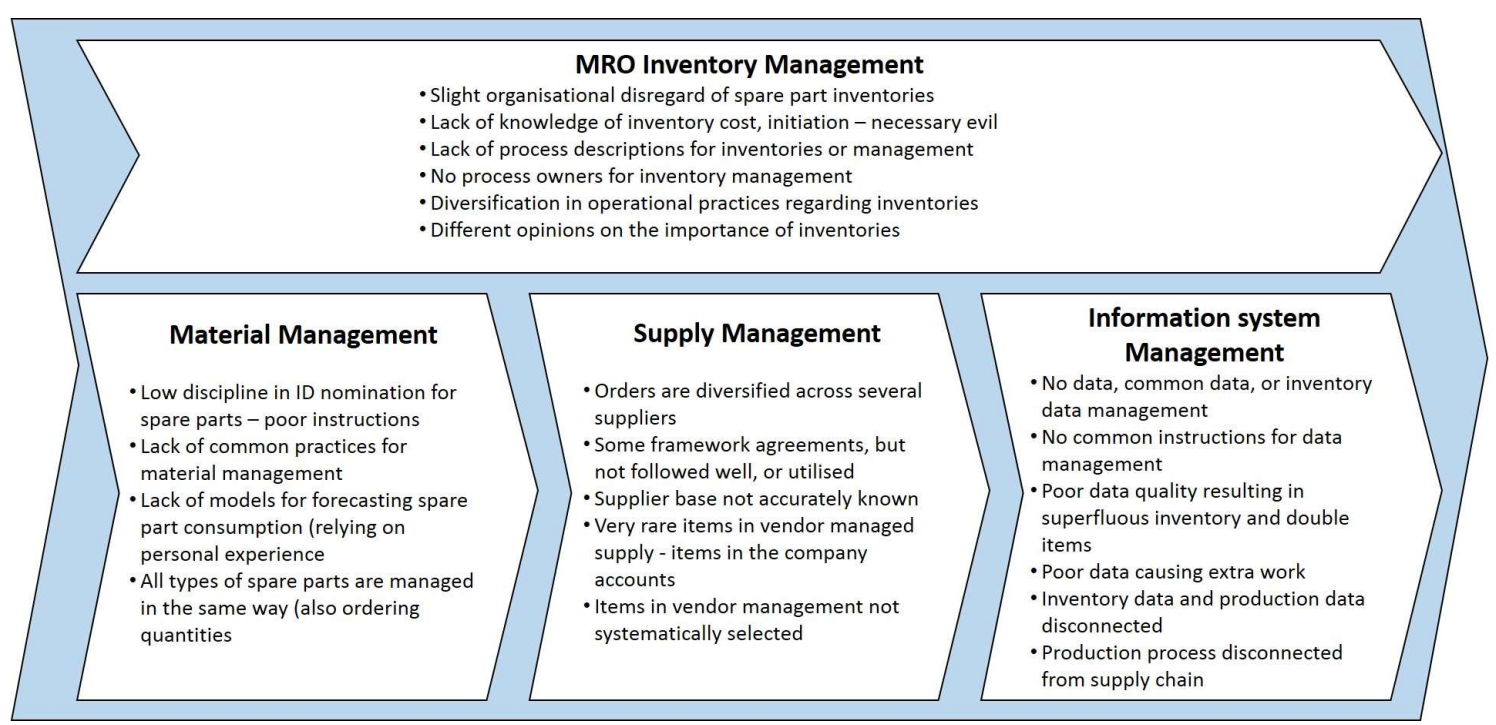

Figure 3. Synthesis of the challenges in the case company. 
Table 2. Challenges faced by MRO operations \& potential solutions.

\begin{tabular}{|c|c|c|c|c|c|}
\hline Challenge & $\begin{array}{l}\text { Department } \\
\text { influenced }\end{array}$ & Cause & Effect & Potential solutions & Indicators \\
\hline $\begin{array}{l}\text { Spare parts and } \\
\text { maintenance targets } \\
\text { cannot be linked }\end{array}$ & $\begin{array}{l}\text { Warehouse, } \\
\text { Maintenance, } \\
\text { Procurement, } \\
\text { IT }\end{array}$ & $\begin{array}{l}\text { Inadequate resources. Issue has not had } \\
\text { enough exposure. Creation of item data is } \\
\text { not controlled. }\end{array}$ & $\begin{array}{l}\text { Warehouse has items that cannot be linked to use. } \\
\text { Procurement unable to adequately estimate } \\
\text { consumption. Non-controlled data in IT system. }\end{array}$ & $\begin{array}{l}\text { Project to complete and revise item data. Project to liaise } \\
\text { with planning engineers. }\end{array}$ & $\begin{array}{l}\text { Percentage of items } \\
\text { without clear linkage } \\
\text { to use. }\end{array}$ \\
\hline Item data quality & $\begin{array}{l}\text { Warehouse, } \\
\text { Maintenance, } \\
\text { Procurement, } \\
\text { IT }\end{array}$ & $\begin{array}{l}\text { Users' data input lacks details/is incorrect. } \\
\text { Guidelines not followed/not known. }\end{array}$ & $\begin{array}{l}\text { Spare part items cannot be located. Duplicates are } \\
\text { created. Item data is not trusted. Unnecessary } \\
\text { procurement actions and wasted efforts. }\end{array}$ & $\begin{array}{l}\text { Monitoring created item data on regular basis. Feedback } \\
\text { to IT system users. Development project to correct } \\
\text { situation. }\end{array}$ & $\begin{array}{l}\text { Ratio of correctly } \\
\text { created item data vs. } \\
\text { all created item data } \\
\text { within a timeframe. }\end{array}$ \\
\hline $\begin{array}{l}\text { ERP order point } \\
\text { planning not fully } \\
\text { utilised }\end{array}$ & $\begin{array}{l}\text { Warehouse, } \\
\text { Maintenance, } \\
\text { Procurement, } \\
\text { IT }\end{array}$ & $\begin{array}{l}\text { Unclear guidelines/purpose not fully } \\
\text { understood. Responsibilities/principles for } \\
\text { setting parameters unclear. }\end{array}$ & $\begin{array}{l}\text { Order size and warehouse balance not optimal. } \\
\text { Variable ways of working in re-order point planning. } \\
\text { Order points set for wrong parts. }\end{array}$ & $\begin{array}{l}\text { Revising guidelines for re-order point planning. Re-order } \\
\text { point setting to be followed alongside item data } \\
\text { monitoring. }\end{array}$ & $\begin{array}{l}\text { Percentage share of } \\
\text { items under re-order } \\
\text { point follow-up. }\end{array}$ \\
\hline $\begin{array}{l}\text { Spare part } \\
\text { procurement } \\
\text { principles not clear }\end{array}$ & $\begin{array}{l}\text { Warehouse, } \\
\text { Maintenance, } \\
\text { Procurement, } \\
\text { Financial, } \\
\text { Management }\end{array}$ & $\begin{array}{l}\text { Procurement related common ways of } \\
\text { working non-existent for procurement } \\
\text { planning/warehousing decisions. }\end{array}$ & $\begin{array}{l}\text { Uncontrollable procurements. Single actor } \\
\text { optimisation. Non-economical warehousing } \\
\text { decisions. }\end{array}$ & $\begin{array}{l}\text { Developing instructions for procurement with clear } \\
\text { principles for procurements and warehousing decisions. }\end{array}$ & $\begin{array}{l}\text { Procurement to } \\
\text { warehouse. }\end{array}$ \\
\hline $\begin{array}{l}\text { Departmental actions } \\
\text { do not support } \\
\text { others/information } \\
\text { exchange lacking }\end{array}$ & All & $\begin{array}{l}\text { Cross-departmental cooperation } \\
\text { lacking/non-existent. }\end{array}$ & $\begin{array}{l}\text { Requirements by departments not acknowledged. } \\
\text { Warehousing negatively influenced by individual } \\
\text { actions. }\end{array}$ & $\begin{array}{l}\text { Clarifying departments with linkages to warehousing. } \\
\text { Development team with covering representation. } \\
\text { Cooperation and development coordinated together. }\end{array}$ & - \\
\hline $\begin{array}{l}\text { Non-awareness of } \\
\text { warehousing } \\
\text { development needs }\end{array}$ & $\begin{array}{l}\text { Management, } \\
\text { Warehouse, } \\
\text { Quality control }\end{array}$ & $\begin{array}{l}\text { No set goals for warehousing. Operations } \\
\text { not assessed/inadequately coordinated. }\end{array}$ & $\begin{array}{l}\text { Management not aware of warehouses' current state. } \\
\text { Development needs not acknowledged impacting } \\
\text { resource allocation. Organisation not committed to } \\
\text { develop warehousing. }\end{array}$ & $\begin{array}{l}\text { Reporting warehouse operations to management. Clear } \\
\text { goal setting with departmental needs acknowledged. } \\
\text { Management focus on continuous development. } \\
\text { Enabling resources. }\end{array}$ & $\begin{array}{l}\text { Warehouse value, } \\
\text { ability to serve, } \\
\text { operational costs of } \\
\text { business unit. }\end{array}$ \\
\hline $\begin{array}{l}\text { Unnecessary } \\
\text { warehouse items }\end{array}$ & $\begin{array}{l}\text { Warehouse, } \\
\text { Maintenance, } \\
\text { IT }\end{array}$ & $\begin{array}{l}\text { Warehouse item needs assessment not } \\
\text { carried out. }\end{array}$ & $\begin{array}{l}\text { Assets tied up in warehouse. Warehousing expenses. } \\
\text { Increased amount of warehouse data. Challenges in } \\
\text { finding items. }\end{array}$ & $\begin{array}{l}\text { Project to carry out inventory/review of warehouse } \\
\text { items. Needs assessment. Update IT system. }\end{array}$ & Warehouse value. \\
\hline $\begin{array}{l}\text { Cooperation - } \\
\text { departments and } \\
\text { warehouse }\end{array}$ & $\begin{array}{l}\text { Warehouse, } \\
\text { Maintenance }\end{array}$ & $\begin{array}{l}\text { Warehoused materials experienced } \\
\text { differently. Common warehousing not } \\
\text { assessed. }\end{array}$ & Same materials in two different warehouses. & List of common materials and number of use targets. & $\begin{array}{l}\text { Number of same } \\
\text { warehoused materials } \\
\text { and spare parts. }\end{array}$ \\
\hline $\begin{array}{l}\text { Warehousing critical } \\
\text { materials with long } \\
\text { delivery time }\end{array}$ & $\begin{array}{l}\text { Warehouse, } \\
\text { Maintenance, } \\
\text { Management }\end{array}$ & $\begin{array}{l}\text { Warehousing cooperation with external } \\
\text { actors non-existent. }\end{array}$ & High warehouse value. & $\begin{array}{l}\text { Listing high value materials and spare part items with } \\
\text { low consumption. Assessment of cooperation } \\
\text { possibilities. }\end{array}$ & - \\
\hline $\begin{array}{l}\text { Scattered supplier } \\
\text { base }\end{array}$ & $\begin{array}{l}\text { Warehouse, } \\
\text { Maintenance, } \\
\text { Procurement }\end{array}$ & $\begin{array}{l}\text { Spare part availability partially weak. } \\
\text { Blanket agreements not known to all. } \\
\text { Supplier base not adequately analysed. }\end{array}$ & $\begin{array}{l}\text { Scattered procurement actions. Weakened } \\
\text { negotiation power. Supplier willingness to serve } \\
\text { non-optimal. }\end{array}$ & $\begin{array}{l}\text { Improving informing on blanket agreements. } \\
\text { Cooperation with suppliers on blanket agreements. } \\
\text { Regular supplier analyses. }\end{array}$ & $\begin{array}{l}\text { Number of suppliers } \\
\text { (/percentage by } \\
\text { procurement class) }\end{array}$ \\
\hline $\begin{array}{l}\text { Supplier information } \\
\text { not available for } \\
\text { analysis }\end{array}$ & $\begin{array}{l}\text { Warehouse, } \\
\text { Maintenance, } \\
\text { Procurement }\end{array}$ & $\begin{array}{l}\text { People in charge of procurement actions do } \\
\text { not adequately link suppliers with supplied } \\
\text { items. }\end{array}$ & $\begin{array}{l}\text { Procurement by suppliers is challenging to realise } \\
\text { reliably. }\end{array}$ & $\begin{array}{l}\text { Clear instructions on linking suppliers and supplied } \\
\text { items. Designated person to follow item data quality. }\end{array}$ & $\begin{array}{l}\text { Ratio of items with } \\
\text { supplier linkage to all } \\
\text { items. }\end{array}$ \\
\hline $\begin{array}{l}\text { Forecasting } \\
\text { individual dependent }\end{array}$ & $\begin{array}{l}\text { Warehouse, } \\
\text { Maintenance }\end{array}$ & $\begin{array}{l}\text { Adequate history data not available/ } \\
\text { challenging utilisation. Supply time } \\
\text { estimations by suppliers not reliable. }\end{array}$ & High warehouse value & $\begin{array}{l}\text { Systematic collection of history data to develop } \\
\text { forecasting methods. Creation of simple forecasting } \\
\text { method. }\end{array}$ & \\
\hline
\end{tabular}




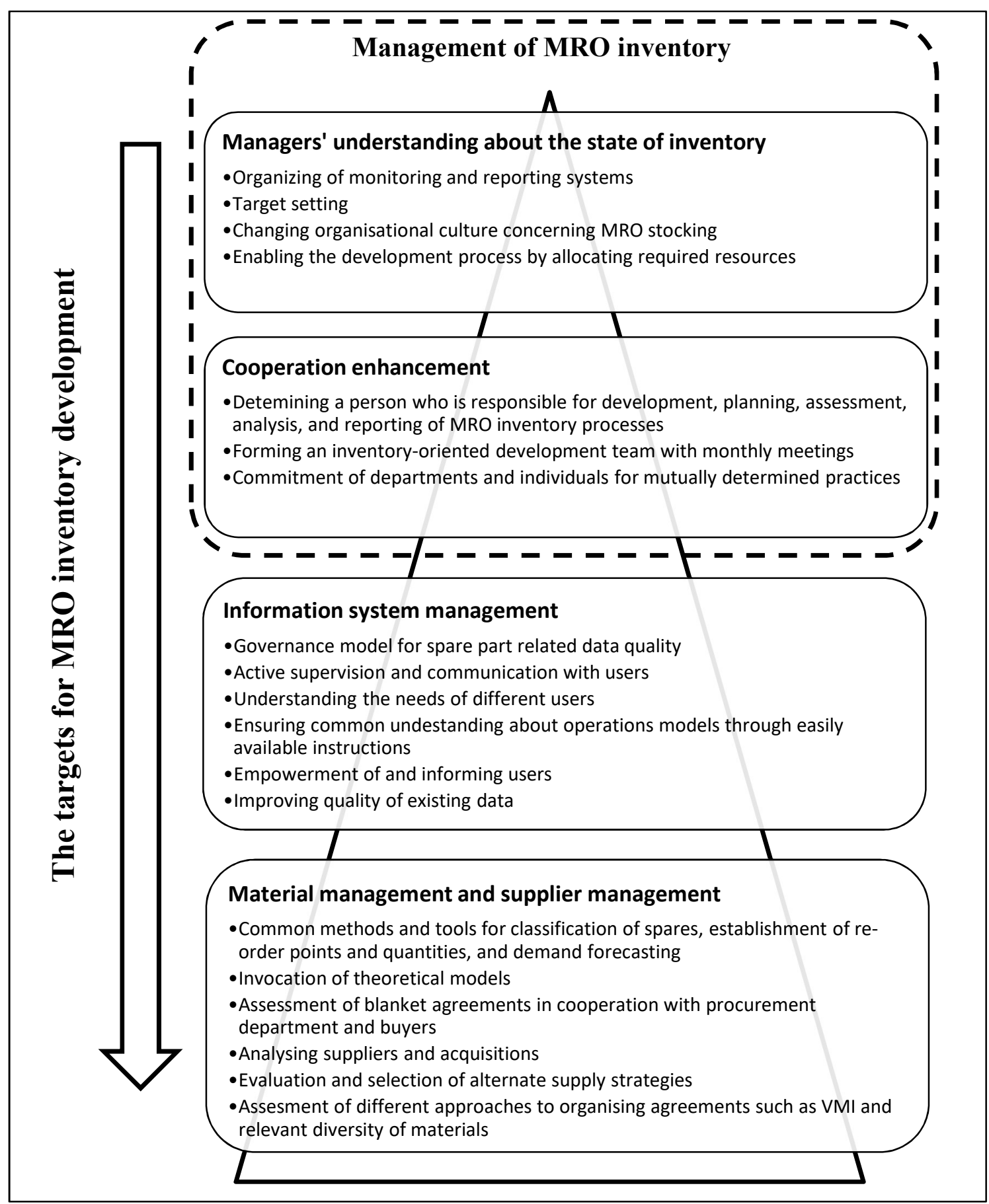

Figure 4. A potential framework for the MRO inventory management development process for capital intensive industries. 